\title{
HUBUNGAN KAUSALITAS WORKPLACE SPIRITUALITY DAN KINERJA KARYAWAN: PERSPEKTIF MEDIASI ETIKA KERJA ISLAM
}

\author{
Moh Rifqi Khairul Umam \\ Institut Agama Islam Negeri Surakarta \\ moh.rifqi@iain-surakarta.ac.id \\ Zakky Fahma Auliya \\ Institut Agama Islam Negeri Surakarta \\ rifqi.elkhoiry@gmail.com
}

\begin{abstract}
Human resource is a very important element in achieving organizational goals. If the organization has a good quality of resources, the organization will be more effective. While the effectiveness of the organization is reflected from the employee performance. The purpose of this study is to examine the effect of workplace spirituality on Islamic work ethic, Islamic work ethic on employee performance, workplace spirituality on employee performance, and the influence of Islamic work ethic as an intervening variable on the relation between workplace spirituality and employee performance, with samples from PKU Muhammadiyah Surakarta Hospital, and IPHI Pedan Hospital, Klaten. The result of the research shows that workplace spirituality has significant effect on Islamic work ethic with, Islamic work ethic has no significant effect to employee performance, workplace spirituality has no significant effect to employee performance, and Islamic work ethic as mediation variable on relation between workplace spirituality (STK) to employee performance has no significant influence.
\end{abstract}

Keywords: Workplace Spirituality, Islamic Work Ethic, Employee Performance

\section{A. Pendahuluan}

Manajemen sumber daya manusia merupakan bagian dari manajemen keorganisasian yang memfokuskan diri pada unsur sumber daya manusia (Rais, Adolfina, \& Dotulong, 2016). Sumber 
daya manusia merupakan unsur yang sangat penting dalam pencapaian tujuan organisasi. Apabila organisasi mempunyai kualitas sumber daya yang baik, maka organisasi akan semakin efektif. Sedangkan efektivitas organisasi tercermin dari hasil kerja karyawannya, atau sering disebut sebagai kinerja karyawan.

Salah satu faktor yang secara empiris dapat mempengaruhi kinerja karyawan adalah nilai spiritualitas di tempat kerja (workplace spirituality). Sebagaimana yang dikemukakan oleh Milliman et., al. (1999) yang mengklaim bahwa nilai spiritualitas memiliki efek positif, baik pada kesejahteraan pribadi maupun kinerja. Hal ini sesuai dengan pernyataan Gani et., al. (2013), dimana spiritualitas memiliki pengaruh yang signifikan terhadap kinerja karyawan, dikarenakan kondisi spiritual yang baik akan meningkatkan kinerja seseorang dalam bekerja, sedangkan agama hanya sebagai moderasi di antara hubungan keduanya. Harrington et al. (2001) menambahkan bahwa semakin banyak nilai dan aspirasi spiritual kongruen dengan organisasi, maka semakin besar kemungkinan bahwa karyawan akan menemukan makna sebenarnya di tempat kerja.

Meskipun literatur dan minat spiritualitas di tempat kerja berkembang pesat, namun masih ditemukan ketidakjelasan dalam penerapannya terhadap kinerja organisasi. Giacalone, Jurkiewicz (2003) dan Fry (2005) menginginkan agar hubungan spiritualitas di tempat kerja terhadap kinerja secara empiris menunjukkan efek positifnya. Tujuan dasarnya adalah membuat area spiritualitas di tempat kerja lebih jelas dan umum untuk studi organisasi. Sehingga penelitian seperti yang dilakukan oleh Pratama (2014) dengan hasil spiritualitas secara parsial tidak berpengaruh terhadap kinerja tidak terulang kembali. Sebab, manfaat spiritualitas di tempat kerja terhadap kinerja mampu untuk mencegah marginalisasi spiritualitas pada tempat kerja.

Selain nilai spiritualitas, peran etika kerja Islam juga patut mendapatkan perhatian khusus, karena faktor tersebut memiliki pengaruh terhadap kinerja karyawan. Dengan adanya etika kerja yang dilandasi dengan dasar-dasar keislaman, bagi karyawan, bekerja akan diniatkan sebagai bagian dari ibadah, sehingga 
setiap pekerjaan akan dapat dijalani dengan ikhlas dan penuh rasa tanggungjawab.

Etika kerja Islam memandang pekerjaan sebagai sarana untuk kepentingan ekonomi, sosial, dan psikologis, untuk dapat mempertahankan martabat sosial, untuk memajukan kesejahteraan masyarakat, dan menegaskan kembali akan iman. Konsep ini berawal dari contoh dan praktik Nabi Muhammad SAW (Ali \& Owaihan, 2008). Etika kerja Islam adalah orientasi yang membentuk dan mempengaruhi keterlibatan partisipasi orang untuk percaya di tempat kerja. Yousef (2008) menekankan kerjasama dalam sebuah pekerjaan, dan konsultasi dipandang sebagai cara untuk mengatasi rintangan dan menghindari kesalahan dalam pekerjaan.

Berdasarkan paparan diatas, tampak bahwa masih terdapat research gap yang pada hubungan antara workplace spirituality dan kinerja karyawan. Atas dasar tersebut, peneliti mengajukan sebuah penelitian dengan judl: "Hubungan Kausalitas Workplace Spirituality dan Kinerja Karyawan: Perspektif Mediasi Etika Kerja Islam".

\section{B. Tinjauan Pustaka}

\section{Kinerja Karyawan}

Mangkunegara et al. (2001) mengungkapkan istilah kinerja berasal dari kata job performance atau actual performance. Pengertian kinerja adalah hasil kerja secara kualitas dan kuantitas yang dicapai oleh seseorang karyawan dalam melaksanakan tugasnya sesuai dengan tanggung jawab yang dibebankan untuknya.

Hasibuan (2011) menyatakan kinerja merupakan perwujudan kerja yang dilakukan oleh karyawan, yang biasanya dipakai sebagai dasar penilaian terhadap karyawan atau organisasi. Kinerja yang baik merupakan langkah untuk mencapai tujuan organisasi, sehingga perlu diupayakan usaha untuk meningkatkan kinerja. Manajemen kinerja adalah keseluruhan kegiatan yang dilakukan untuk meningkatkan kinerja perusahaan atau organisasi, termasuk kinerja masing-masing individu dan kelompok kerja di perusahaan tersebut (Rosita \& Yuniati, 2016). 
Mathis dan Jackson (2002: 378) membagi indikator kinerja karyawan menjadi 5 indikator, yaitu:
a. Kuantitas kerja karyawan
b. Kualitas kerja karyawan
c. Ketepatan waktu
d. Kehadiran di tempat kerja
e. Sikap kooperatif

\section{Workplace Sprituality (Spiritualitas di Tempat Kerja)}

Ashmos dan Duchon (2000) mendeskripsikan spiritualitas di tempat kerja terkait dalam dua aspek: pengalaman individu dan lingkungan organisasi. Mereka mendefinisikan spiritualitas di tempat kerja muncul karena individu dapat mengekspresikan diri secara pribadi dengan melakukan arti kerja dalam komunitas mereka.

Dalam hal ini, Ashmos dan Duchon (2000) mengembangkan dimensi spiritualitas di tempat kerja menjadi tiga dimensi, yaitu: arti kerja, perasaan menjadi bagian dari komunitas dalam pekerjaan, dan nilai keselarasan. Dimensi arti kerja menunjukkan tingkat perasaan mendalam yang dirasakan oleh seorang individu tentang arti dan tujuan bekerja. Dimensi perasaan menjadi bagian dari komunitas dalam pekerjaan, yaitu bahwa karyawan telah menjadi bagian dari orang lain dan bagian dari komunitas tempat kerja. Adapun dimensi nilai keselarasan adalah perasaan yang kuat yang dirasakan oleh seorang individu tentang bagaimana nilai-nilai pribadi menjadi satu dengan misi dan tujuan organisasi.

Dalam konteks lingkungan kerja, spiritualitas dapat diidentifikasi melalui dua tingkatan menurut Giacalone dan Jurkiewicz (2003), yaitu:

a. Tingkat individu: tingkat yang mengacu pada seperangkat nilai-nilai yang mendorong pengalaman transenden individu melalui proses kerja dengan memfasilitasi perasaan yang terhubung dengan orang lain.

b. Tingkat organisasi: tingkat ini mengacu pada kerangka nilai-nilai budaya organisasi yang mendorong pengalaman transenden karyawan melalui proses kerja dengan memfasilitasi perasaan yang terhubung dengan orang lain. 
Orang yang bekerja biasanya mempertimbangkan spiritualitas sebagai alat untuk meningkatkan kesempurnaan, motivasi, dan kepuasan pekerjaan. Agama juga membantu kelangsungan spiritualitas meskipun dapat memisahkan orang dari satu sama lain. Kemampuan spiritualitas untuk mendorong kebiasaan baik dan moral yang merupakan kriteria yang tepat untuk menguji pengaruh spiritualitas dalam bisnis. Banyak manajer yang sukses mewakili spiritualitas dengan cara meningkatkan kebiasaan etis yang menyenangkan bagi mereka (Cavanagh \& Banduch, 2002).

Baru-baru ini, kombinasi kehidupan spiritual dan kehidupan organisasi karyawan telah menjadi objek studi organisasi dan ilmu manajemen. Spiritualitas merupakan upaya untuk mendidik orang bagaimana berurusan dengan dirinya sendiri, dengan orang lain, dan makhluk lain selain manusia, serta berhubungan dengan Tuhan, atau untuk mengeksplorasi di jalur yang diperlukan. Spiritualitas memperkuat apa yang orang lakukan dan akan diperkuat oleh mereka pada gilirannya. Dengan meningkatkan perilaku etika dan moral pada individu, spiritualitas menciptakan komitmen seseorang terhadap organisasi, dimana orang tersebut akan mengasimilasikan tujuan dan nilai-nilainya dengan tujuan dan nilai-nilai organisasi.

Menurut Ashmos Duchon (2000), terdapat beberapa indikator dalam workplace spirituality ini, antara lain:

a. Kondisi lingkungan atau kelompok

b. Kebermaknaan pada pekerjaan

c. Hakikat yang dirasakan dalam diri

d. Pemahaman spiritualitas yang jelas

e. Tanggungjawab secara pribadi

f. Menjalin hubungan yang baik dengan orang lain

g. Kontemplasi/perenungan diri

Adapun manfaat spiritualitas di tempat kerja antara lain:

a. Spiritualitas di tempat kerja mendorong karyawan untuk lebih berkomitmen terhadap organisasi, sehingga mampu menurunkan tingkat absensi dan keluar masuknya karyawan (Fry, 2003).

b. Karyawan menganggap bahwa partisipasi yang aktif adalah partisipasi yang dipengaruhi oleh kinerja karyawan, sebab 
tingkat kepentingan pekerjaan berhubungan dengan citra diri seseorang (Kolodinsky et al., 2008).

c. Spiritualitas digunakan sebagai motif bekerja secara individual, dan secara interaktif spiritualitas personal dan organisasi mampu mempengaruhi penghargaan karyawan terhadap pekerjaannya (Kumpikaite, 2009).

Organisasi spiritual cenderung lebih partisipatif dan inklusif dalam membuat keputusan dan berbagi informasi, sehingga membantu karyawan merasa berdaya dan penting (Kolodinsky et., al., 2008).

\section{Etika Kerja Islam}

Istilah etika seringkali dibandingkan dengan moralitas. Etika dan moralitas sering dipertukarkan atau diberikan pengertian yang sama. Hal tersebut tidak sepenuhnya salah, hanya saja perlu diperhatikan bahwa etika bisa memiliki pengertian yang sangat berbeda dengan moralitas (Nurmatias, 2015). Dengan demikian, etika merupakan penjabaran rasional yang terkandung dalam aturan praktis untuk menunjukkan sesuatu yang baik dan benar.

A.J. Ali dan Owaihan (2008) menerangkan bahwa konsep etika dalam Islam tidak hanya dikaitkan dengan perilaku baik buruk, namun didalamnya juga terkandung dimensi ekonomi, moral, dan sosial. Dimensi ekonomi berhubungan dengan cara pemenuhan kebutuhan hidup yang memperhatikan kaidah etika Islam dalam pemenuhannya. Dimensi moral berkaitan dengan perilaku baik buruk individu dalam mencapai pemenuhan kebutuhannya. Sedangkan dimensi sosial merujuk pada pemenuhan kebutuhan sosial seorang individu dalam berhubungan dengan sesamanya, sehingga tidak merugikan satu sama lain.

Etika dalam Islam juga menganjurkan bagi individu untuk selalu setia terhadap organisasi yang dapat menimbulkan rasa kelayakan diri untuk bergabung dalam organisasi. Lebih lanjut, dengan etika kerja Islam, mereka akan berkomitmen terhadap organisasi (A.J. Ali dan Owaihan, 2008). Individu yang setia terhadap organisasi akan selalu bekerja untuk organisasi. Hal ini sesuai dengan pandangan Islam mengenai orang yang bekerja. Akan tetapi Budiman (2009) menemukan etika kerja Islam tidak 
mempunyai pengaruh yang signifikan terhadap kinerja karyawan KJKS BMT di Kecamatan Rembang.

Penelitian yang dilakukan oleh Chanzanagh dan Akbarnejad (2011) menyebutkan ada enam dimensi etika kerja Islam, yaitu:

a. Kepercayaan

b. Niat bekerja

c. Jenis pekerjaan

d. Islamic ummah

e. Keadilan

f. Kerjasama.

Hasil temuan mereka menjelaskan bahwa tingkat etika kerja Islam di Iran diatas rata-rata, dimana pekerja dari kelas menengah kebawah memiliki skor yang lebih tinggi daripada pekerja menengah ke atas.

\section{Penelitian yang Relevan dan Pengembangan Hipotesis}

Milliman et., al. (1999) menemukan bahwa nilai spiritualitas memiliki efek positif, baik pada kesejahteraan pribadi maupun pada kinerja karyawan. Hal ini sesuai dengan pernyataan Gani et., al. (2013) bahwa spiritualitas memiliki pengaruh yang signifikan terhadap kinerja karyawan, sebab kondisi spiritual yang baik akan meningkatkan kinerja seseorang dalam bekerja, sedangkan agama hanya sebagai moderasi di antara hubungan keduanya. Harrington et., al. (2001) juga menambahkan bahwa semakin banyak nilai dan aspirasi spiritual kongruen dengan organisasi, semakin besar kemungkinan bahwa karyawan akan menemukan makna sebenarnya di tempat kerja. Adapun Soha et., al. 2016) menyebutkan bahwa spiritualitas di tempat kerja mampu dijadikan sebagai faktor individu dalam organisasi untuk mempengaruhi kinerja organisasi. Albuquerque et al. (2014) merinci hubungan tersebut melalui penelitiannya, bahwa kinerja dapat dibangun dengan rasa kebersamaan (sense of community), serta rasa dari tujuan dan pekerjaan yang berarti (sense of purpose and meaning work).

Etika memiliki pengaruh yang besar dalam tingginya kinerja seorang karyawan, dibuktikan dengan penelitian yang ditemukan oleh Chanzanagh \& Akbarnejad (2011); Hayati dan Caniago (2012); A.J. Ali dan Owaihan (2008); Nizam et al. (2016); Nurmatias (2015); 
Aji (2010), dan Yousef (2008). Nilai spiritualitas pun dinyatakan memiliki pengaruh terhadap etika kerja Islam. Hal ini dibuktikan dari Giacalone dan Jurkiewicz (2003) yang menemukan bukti bahwa spiritualitas akan berkorelasi dengan persepsi pelanggaran etika yang lebih tinggi dalam kasus ketika legalitas suatu isu yang diberikan tidak jelas.

Dari beberapa hasil penelitian empiris diatas, berikut kerangka berpikir dan hipotesis yang diajukan:

Gambar. 1 Kerangka Berpikir

\begin{tabular}{ll}
\hline $\mathrm{H}_{1}:$ & $\begin{array}{l}\text { Diduga ada pengaruh signifikan workplace spirituality } \\
\text { terhadap etika kerja Islam }\end{array}$ \\
\hline $\mathrm{H}_{2}:$ & $\begin{array}{l}\text { Diduga ada pengaruh signifikan etika kerja Islam terhadap } \\
\text { kinerja karyawan }\end{array}$ \\
\hline $\mathrm{H}_{3}:$ & $\begin{array}{l}\text { Diduga ada pengaruh signifikan workplace spirituality } \\
\text { terhadap kinerja karyawan }\end{array}$ \\
\hline
\end{tabular}

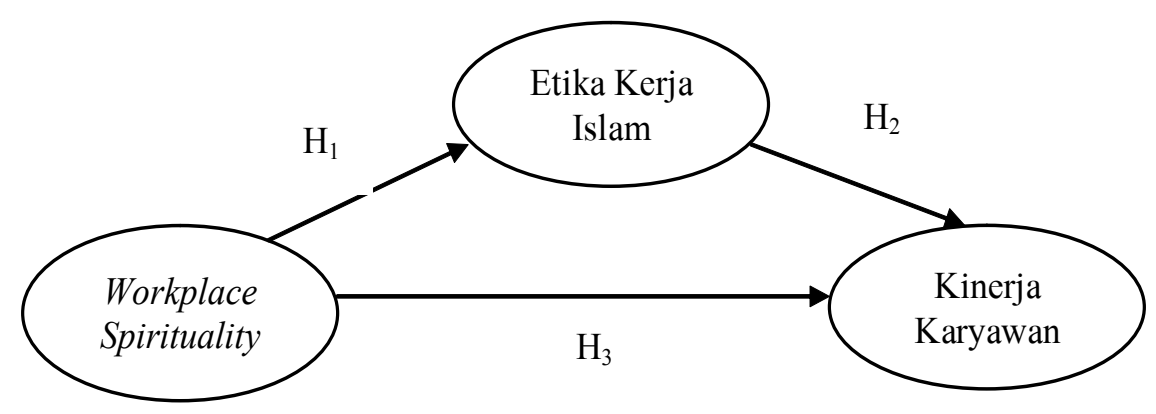

\section{Metode}

\section{Populasi}

Populasi dalam penelitian ini adalah seluruh tenaga medis dan non medis yang ada di dua Rumah Sakit dibawah Yayasan Islam, yang berada di wilayah kota Surakarta dan Klaten, yakni: Rumah Sakit PKU Muhammadiyah Surakarta dan Rumah Sakit IPHI Pedan, Klaten, dengan jumlah keseluruhan populasi sebanyak 980 orang. Peneliti mengambil tenaga medis dan non medis pada Rumah Sakit dibawah Yayasan Islam sebagai responden dari objek penelitian dikarenakan beberapa variabel yang diangkat dalam penelitian ini mengarah pada variabel dengan muatan nilai Islam, 
yakni nilai spiritualitas di tempat kerja (workplace spirituality) dan etika kerja Islam. Semua karyawan yang bekerja di Rumah Sakit yang dijadikan sebagai objek penelitian beragama Islam, dan Rumah Sakit dinilai telah secara aktif mengaplikasikan berbagai nilai keislaman dalam menjalankan manajemen SDM di dalam organisasinya.

\section{Sampel}

Dikarenakan penelitian ini menggunakan teknik analisis multivariat dengan menggunakan Structural Equation Modelling (SEM), maka kriteria pengambilan sampel juga menggunakan standar dari SEM tersebut. Ukuran sampel yang sesuai untuk SEM adalah antara 100 sampai dengan 200 sampel (Ferdinand, 2014: 173).

\section{Teknik Pengambilan Sampel}

Dalam penelitian ini, teknik pengambilan data yang digunakan adalah teknik probability sampling. Setiap anggota populasi mempunyai kesempatan yang sama untuk menjadi anggota sampel penelitian. Secara spesifik, teknik yang digunakan adalah convenience sampling. Teknik pengambilan data ini merupakan teknik yang sederhana, karena kuesioner dapat disebar kepada semua populasi yang ada, dan mereka bersedia untuk menjawab pertanyaan kuesioner (Kuncoro, 2009: 189).

\section{Teknik Pengumpulan Data}

Pengumpulan data dilakukan dengan survei kuesioner, yaitu suatu metode pengumpulan data dengan memberikan atau menyebarkan daftar pertanyaan kepada para responden. Setiap responden diminta pendapatnya dengan memberikan jawaban dari pertanyaan yang diajukan. Data dikumpulkan dengan menggunakan angket, yaitu dengan mengajukan pertanyaanpertanyaan untuk mendapatkan data tentang indikator-indikator dari konstruk-konstruk yang sedang dikembangkan dalam penelitian ini. 


\section{Teknik Analisis Data}

\section{a. Uji Validitas dan Reliabilitas}

Sebelum penelitian dilakukan, perlu dilakukan pengujian terhadap validitas dan reliabilitas terhadap daftar pertanyaan yang digunakan. Pengujian validitas dan reliabilitas daftar pertanyaan ini dimaksudkan agar daftar pertanyaan yang digunakan untuk mendapatkan data penelitian memiliki tingkat validitas dan reliabilitas yang memenuhi batasan yang disyaratkan.

b. Analisis Data

Selanjutnya, untuk menganalisis data, peneliti menggunakan metode analisis Structural Equation Modelling (SEM) yang dioperasikan melalui program paket software statistic AMOS. SEM merupakan kombinasi dari analisis faktor dan analisis regresi. Teknik SEM memungkinkan seorang peneliti menguji beberapa variabel dependen sekaligus, dengan beberapa variabel independen. SEM merupakan sekumpulan teknik statistik yang dapat digunakan untuk menganilisis permasalahan penelitian yang memiliki rangkaian hubungan yang relatif rumit dengan pengujian statistik secara simultan (Ferdinand, 2002).

Secara garis besar, penelitian ini menggunakan dua macam teknik analisis, yang dilakukan secara bertahap, yaitu:

1) Model pengukuran (measurement model)

Mesurement model atau model pengukuran ditujukan untuk mengkonfirmasi dimensi-dimensi yang dikembangkan pada sebuah variabel/faktor yang diteliti. Variabel-variabel penelitian akan diuji unidimensionalitasnya dalam membentuk variabel laten (Ferdinand, 2002). Unidimensionalitas adalah kemampuan indikator untuk dapat mengukur satu konstruk (Hair et al., 1995). Unidimensionalitas skala diestimasi dengan uji validitas konstruk melalui pendekatan validitas konvergen (convergent validity) dan validitas diskriminan (discriminant validity). 
2) Model struktural (structural model)

Structural model adalah model mengenai struktur hubungan yang membentuk atau menjelaskan kausalitas antar variabel/ faktor yang diteliti. Dengan program ini juga akan diukur hubungan sebab akibat antara berbagai konsep variabel yang akan diukur. Pengujian hipotesis dilakukan melalui goodness of fit dari model penelitian dan hubungan dalam model yang disampaikan (Hair et al., 1995).

Structural model menghasilkan validitas prediktif (predictive validity). Validitas prediktif menunjukkan kemampuan instrumen membedakan individu dalam kriteria masa depan. Validitas ini dapat diukur dengan koefisien korelasi antara skor instrumen pengukur dengan skor hasil masa depan yang seharusnya tinggi.

Menurut Ferdinand (2002) sebuah pemodelan SEM mensyaratkan adanya ukuran sampel, normalitas data, tidak hanya outliers, serta tidak adanya masalah dalam multicollinearity dan singularity. Hair et., al., (1995) mengemukakan ada tujuh langkah yang harus dilakukan apabila menggunakan Structural Equation Modelling (SEM), yaitu pengembangan model teoritis, pengembangan diagram alur (path diagram), memilih matriks input dan estimasi model, kemungkinan munculnya masalah identifikasi, evaluasi kriteria goodness of fit, dan interpretasi dan modifikasi.

\section{Hasil Dan Pembahasan}

\section{Deskripsi Data}

Responden dalam penelitian ini adalah karyawan tetap pada Rumah Sakit PKU Muhammadiyah Surakarta dan Rumah Sakit IPHI Pedan, Klaten, baik tenaga medis maupun non medis. Setelah melalui penyaringan data dan menghilangkan outlier pada data, pada penelitian ini diambil sampel sebanyak 117 responden. Metode analisis data yang digunakan adalah Structural Equation Modelling (SEM). Pengambilan sampel menggunakan teknik probability sampling, dengan metode simple random sampling. 
Moh Rifqi Khairul Umam \& Zakky Fahma Auliya

\section{Analisis Data}

\section{a. Validitas}

Gambar. 2

Model Penelitian dalam SEM

Sumber: Data yang Diolah (2017)

Tabel. 3

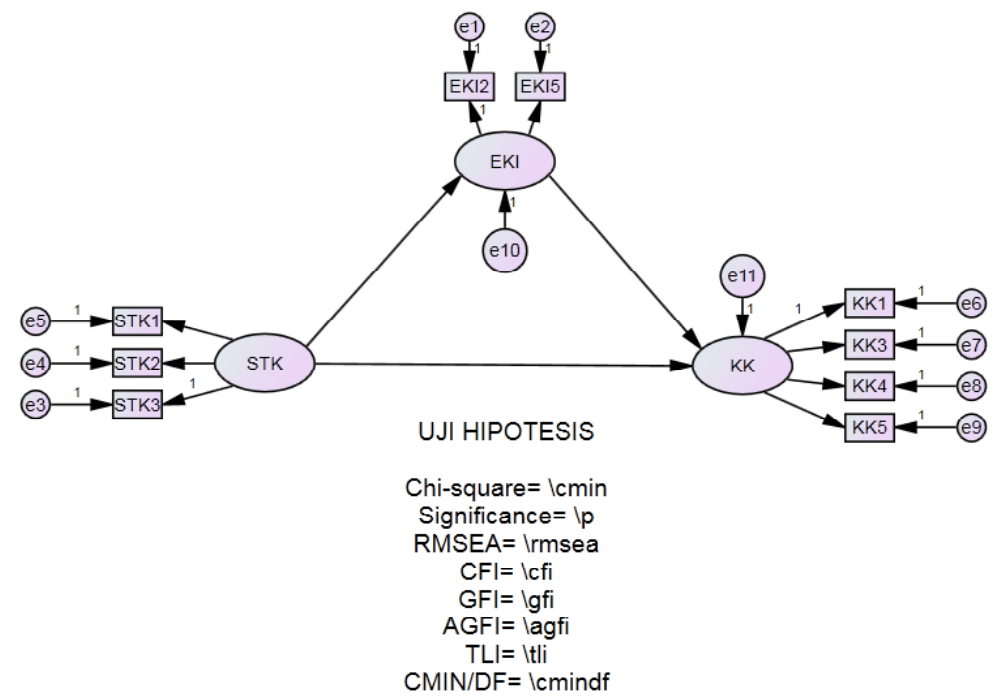

Convergent Validity

\begin{tabular}{lccc}
\hline EKI2 & $<---$ & EKI & .671 \\
\hline EKI5 & $<---$ & EKI & .485 \\
\hline STK3 & $<---$ & STK & .627 \\
\hline STK2 & $<---$ & STK & .708 \\
\hline STK1 & $<---$ & STK & .530 \\
\hline KK1 & $<---$ & KK & .601 \\
\hline KK3 & $<---$ & KK & .537 \\
\hline KK4 & $<---$ & KK & .480 \\
\hline KK5 & $<---$ & KK & .712 \\
\hline
\end{tabular}

Sumber: Data yang Diolah (2017)

Dari semua semua indikator diatas, dapat dilihat bahwa hasil dari semua instrumen yang digunakan untuk mengukur indikator dinyatakan valid, karena telah memenuhi bobot faktor diatas 0,5, yang sesuai dengan batasan nilai convergent validity (Ghozali dan Latan, 2015: 76-77). 


\section{b. Reliabilitas}

Standarized loading diperolah dari standarized loading untuk tiap-tiap indikator, sedangkan $\varepsilon j$ adalah measurement error didapat dari 1-( (Standarized loading $)^{2}$, dengan menggunakan rumus sebagai berikut (Ghozali, 2014:233):

Dari rumus diatas, didapatkan perhitungan sebagai berikut:

1) Spiritualitas Tempat Kerja 0,655

2) Kinerja Karyawan

$$
\text { Construct Reliability }=\frac{\left(\sum \text { Standarized loading }\right)^{2}}{\left(\sum \text { Standarized loading }\right)^{2}+\sum \varepsilon j}
$$

3) Etika Kerja Islam

$$
\begin{aligned}
& \text { Construct Reliability }=\frac{(1,87)^{2}}{(1,87)^{2}+1,82}=\frac{3,48}{3,48+1,82}=\frac{3,48}{5,3}= \\
& 0,504
\end{aligned}
$$

Dapat dilihat diatas bahwa reliabilitas dari semua variabel Construct Reliability $=\frac{(2,33)^{2}}{(2,33)^{2}+2,61}=\frac{5,42}{5,42+2,61}=\frac{5,42}{8,03}=$

adalah lebih dari 0,50 . Standar reliabilitas variance extracted dalam SEM minimal 0,50 (Ferdinand, 2014:62-64). Maka kesemuanya

$$
\text { Construct Reliability }=\frac{(1,16)^{2}}{(1,16)^{2}+1,31}=\frac{1,33}{1,33+1,31}=\frac{1,33}{2,64}=
$$

dinyatakan reliabel/handal.

\section{c. Uji Goodness of Fit}

Pengujian ini dilakukan bertahap sampai memenuhi model yang tepat sesuai dengan cut off value. Goodness of fit indices yang digunakan adalah chi-square, significance, RMSEA, CFI, GFI, AGFI, TLI, dan CMIN/DF. Apabila belum diperoleh model yang baik, maka perlu dilakukan modifikasi model agar memenuhi syarat kelayakan model. Hasil output SEM terkait goodness of fit model penelitian ini digambarkan pada gambar. 4 dan table. 4 sebagai berikut:

Gambar. 4

Model Struktural 
Tabel. 5

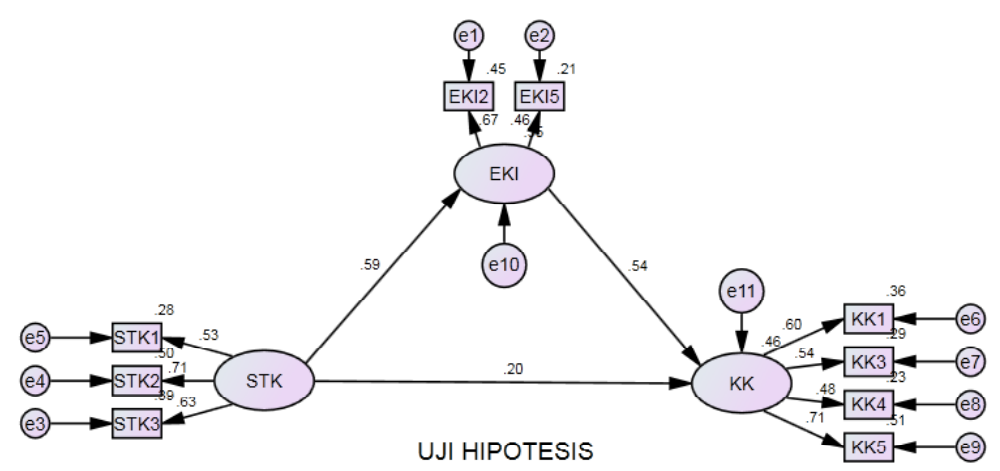

$$
\begin{gathered}
\text { Chi-square }=28.740 \\
\text { Significance }=.230 \\
\text { RMSEA }=.041 \\
\text { CFI }=.970 \\
\text { GFI }=.946 \\
\text { AGFI }=.898 \\
\text { TLI }=.956 \\
\text { CMIN/DF }=1.197
\end{gathered}
$$

Goodness of Fit Index (Uji Kelayakan Model)

\begin{tabular}{llccc}
\hline No. Goodness of Fit Index & Cut off value & Hasil & $\begin{array}{c}\text { Evaluasi } \\
\text { Model }\end{array}$ \\
\hline 1 & Chi Square & Diharapkan Kecil & 28,740 & Fit \\
\hline 2 & Significanced Probability & $\geq 0,05$ & 0,230 & Fit \\
\hline 3 & RMSEA & Antara $0.03-0,08$ & 0,041 & Fit \\
\hline 4 & GFI & $\geq 0,90<1$ & 0,946 & Fit \\
\hline 5 & AGFI & $\geq 0,90<1$ & 0,898 & Marginal Fit \\
\hline 6 & CMIN/DF & $\leq 2,00$ & 1,197 & Fit \\
\hline 7 & TLI & $\geq 0,95<1$ & 0,956 & Fit \\
\hline 8 & CFI & $\geq 0,95<1$ & 0,970 & Fit \\
\hline
\end{tabular}

Sumber: Data yang Diolah (2017)

Dari gambar 5. di atas, diketahui bahwa nilai semua nilai goodness of fit indices memenuhi kriteria cut off value. Hal ini menunjukkan bahwa model pada penelitian ini bisa dilanjutkan ke uji selanjutnya. 


\section{Uji Asumsi SEM}

\section{a. Uji Pengukuran Sampel}

Jumlah sampel dalam penelitian ini adalah 117 responden. Jumlah sampel ini telah memenuhi syarat ukuran sampel yang sesuai untuk SEM, yakni antara 100 sampai dengan 200 sampel (Ferdinand, 2014:173). Jika jumlah sampel tidak sesuai syarat ukuran sampel dalam SEM, maka akan sulit mendapatkan ukuran goodness of fit (Ferdinand, 2014: 54).

\section{b. Uji Normalitas}

Evaluasi normalitas data dapat dilihat dari melihat nilai critical ratio skewness value sebesar $\pm 2,58$ pada tingkat signifikansi 0,01 (1\%). Data dikatakan terdistribusi normal jika pada nilai critical ratio skewness value di bawah $\pm 2,58$ (Ferdinand, 2014: 64). Normalitas data pada penelitian ini dapat dilihat pada tabel 4.3. sebagai berikut:

Tabel. 6

Normalitas Data

\begin{tabular}{lcccccc}
\hline Variable & Min & Max & Skew & c.r. & Kurtosis & c.r. \\
\hline KK5 & 3.000 & 5.000 & .325 & 1.433 & -.009 & -.019 \\
\hline KK4 & 3.000 & 5.000 & .482 & 2.127 & .659 & 1.455 \\
\hline KK3 & 3.000 & 5.000 & .501 & 2.213 & 2.110 & 4.658 \\
\hline KK1 & 3.000 & 5.000 & .504 & 2.224 & 2.380 & 5.255 \\
\hline STK1 & 2.000 & 5.000 & -.454 & -2.005 & 7.402 & 16.344 \\
\hline STK2 & 3.000 & 5.000 & .485 & 2.140 & 1.638 & 3.617 \\
\hline STK3 & 2.000 & 5.000 & -.358 & -1.579 & 3.099 & 6.842 \\
\hline EKI5 & 3.000 & 5.000 & .405 & 1.788 & .286 & .631 \\
\hline EKI2 & 3.000 & 5.000 & .175 & .774 & 1.128 & 2.490 \\
\hline Multivariate & & & & & 61.425 & 23.609 \\
\hline Sumber : Dat & & & & & &
\end{tabular}

Sumber : Data yang Diolah (2017)

Dari table. 6 diatas, dapat dilihat besaran nilai critical ratio skewness value yang semua dibawah $\pm 2,58$, dimana standar normalitas skewness value CR adalah $\pm 2,58$ (Ferdinand, 2014: 62-64). Maka data secara keseluruhannya dapat dinyatakan terdistribusi dengan normal, sehingga pengujian data dapat dilanjutkan ke uji selanjutnya. 
Moh Rifqi Khairul Umam \& Zakky Fahma Auliya

\section{c. Evaluasi Outlier}

Adanya outlier dapat diketahui dengan statistik chi square terhadap nilai Mahalanobis distance squared pada tingkat signifikansi 0,00 dengan degree of freedom sejumlah konstruk yang digunakan dalam penelitian (Ghozali, 2014: 85). Evaluasi outlier dapat dilihat melalui tabel 4.4. berikut:

Tabel. 7

\section{Evaluasi Outlier}

\begin{tabular}{|c|c|c|c|}
\hline $\begin{array}{c}\text { Observation } \\
\text { number }\end{array}$ & $\begin{array}{c}\text { Mahalanobis } \\
\text { d-squared }\end{array}$ & $\mathrm{p} 1$ & $\mathrm{p} 2$ \\
\hline 7 & 47.676 & .000 & .000 \\
\hline 20 & 39.417 & .000 & .000 \\
\hline 108 & 31.242 & .000 & .000 \\
\hline 92 & 23.912 & .004 & .002 \\
\hline 30 & 23.362 & .005 & .000 \\
\hline 10 & 23.155 & .006 & .000 \\
\hline 11 & 22.507 & .007 & .000 \\
\hline 40 & 22.455 & .008 & .000 \\
\hline 29 & 21.155 & .012 & .000 \\
\hline 105 & 21.009 & .013 & .000 \\
\hline 113 & 20.230 & .017 & .000 \\
\hline 32 & 19.310 & .023 & .000 \\
\hline 51 & 19.131 & .024 & .000 \\
\hline 14 & 18.951 & .026 & .000 \\
\hline 60 & 18.466 & .030 & .000 \\
\hline 109 & 18.105 & .034 & .000 \\
\hline 106 & 17.685 & .039 & .000 \\
\hline 116 & 17.452 & .042 & .000 \\
\hline 31 & 17.212 & .046 & .000 \\
\hline 93 & 17.186 & .046 & .000 \\
\hline 3 & 17.156 & .046 & .000 \\
\hline 8 & 16.469 & .058 & .000 \\
\hline 86 & 16.469 & .058 & .000 \\
\hline 117 & 16.019 & .066 & .000 \\
\hline 91 & 15.781 & .072 & .000 \\
\hline 66 & 15.734 & .073 & .000 \\
\hline 98 & 15.508 & .078 & .000 \\
\hline 110 & 15.463 & .079 & .000 \\
\hline 87 & 15.417 & .080 & .000 \\
\hline
\end{tabular}


Hubungan Kausalitas Workplace Spirituality...

\begin{tabular}{|c|c|c|c|}
\hline $\begin{array}{c}\text { Observation } \\
\text { number }\end{array}$ & $\begin{array}{c}\text { Mahalanobis } \\
\text { d-squared }\end{array}$ & p1 & p2 \\
\hline 99 & 15.078 & .089 & .000 \\
\hline 19 & 14.920 & .093 & .000 \\
\hline 97 & 14.837 & .096 & .000 \\
\hline 45 & 14.813 & .096 & .000 \\
\hline 64 & 14.538 & .104 & .000 \\
\hline 17 & 14.215 & .115 & .000 \\
\hline 44 & 13.986 & .123 & .000 \\
\hline 68 & 13.873 & .127 & .000 \\
\hline 43 & 13.161 & .155 & .000 \\
\hline 65 & 12.394 & .192 & .000 \\
\hline 18 & 11.990 & .214 & .001 \\
\hline 115 & 11.990 & .214 & .000 \\
\hline 55 & 11.926 & .218 & .000 \\
\hline 42 & 11.562 & .239 & .001 \\
\hline 102 & 11.262 & .258 & .003 \\
\hline 5 & 11.196 & .263 & .003 \\
\hline 36 & 10.641 & .301 & .021 \\
\hline 53 & 10.641 & .301 & .013 \\
\hline 4 & 10.496 & .312 & .015 \\
\hline 52 & 9.593 & .384 & .251 \\
\hline 35 & 9.022 & .435 & .603 \\
\hline 25 & 8.916 & .445 & .614 \\
\hline 67 & 8.380 & .496 & .888 \\
\hline 28 & 8.294 & .505 & .888 \\
\hline 107 & 8.294 & .505 & .848 \\
\hline 114 & 8.294 & .505 & .801 \\
\hline 2 & 8.174 & .517 & .820 \\
\hline 49 & 7.633 & .571 & .973 \\
\hline 56 & 7.633 & .571 & .959 \\
\hline 38 & 7.471 & .588 & .973 \\
\hline 48 & 7.471 & .588 & .959 \\
\hline 22 & 6.907 & .647 & .998 \\
\hline 21 & 6.690 & .669 & .999 \\
\hline 27 & 6.690 & .669 & .999 \\
\hline 47 & 6.292 & .710 & 1.000 \\
\hline 70 & 6.292 & .710 & 1.000 \\
\hline 69 & 5.912 & .749 & 1.000 \\
\hline 72 & 5.912 & .749 & 1.000 \\
\hline
\end{tabular}


Moh Rifqi Khairul Umam \& Zakky Fahma Auliya

\begin{tabular}{|c|c|c|c|}
\hline $\begin{array}{c}\text { Observation } \\
\text { number }\end{array}$ & $\begin{array}{c}\text { Mahalanobis } \\
\text { d-squared }\end{array}$ & $\mathrm{p} 1$ & p2 \\
\hline 63 & 5.430 & .795 & 1.000 \\
\hline 57 & 5.296 & .808 & 1.000 \\
\hline 62 & 5.296 & .808 & 1.000 \\
\hline 73 & 5.296 & .808 & 1.000 \\
\hline 101 & 5.296 & .808 & 1.000 \\
\hline 26 & 5.211 & .816 & 1.000 \\
\hline 96 & 5.211 & .816 & 1.000 \\
\hline 12 & 3.818 & .923 & 1.000 \\
\hline 95 & 3.818 & .923 & 1.000 \\
\hline 104 & 3.818 & .923 & 1.000 \\
\hline 1 & .337 & 1.000 & 1.000 \\
\hline 6 & .337 & 1.000 & 1.000 \\
\hline 9 & .337 & 1.000 & 1.000 \\
\hline 13 & .337 & 1.000 & 1.000 \\
\hline 15 & .337 & 1.000 & 1.000 \\
\hline 16 & .337 & 1.000 & 1.000 \\
\hline 23 & .337 & 1.000 & 1.000 \\
\hline 24 & .337 & 1.000 & 1.000 \\
\hline 33 & .337 & 1.000 & 1.000 \\
\hline 34 & .337 & 1.000 & 1.000 \\
\hline 37 & .337 & 1.000 & 1.000 \\
\hline 39 & .337 & 1.000 & 1.000 \\
\hline 41 & .337 & 1.000 & 1.000 \\
\hline 46 & .337 & 1.000 & 1.000 \\
\hline 50 & .337 & 1.000 & 1.000 \\
\hline 54 & .337 & 1.000 & 1.000 \\
\hline 58 & .337 & 1.000 & 1.000 \\
\hline 59 & .337 & 1.000 & 1.000 \\
\hline 61 & .337 & 1.000 & 1.000 \\
\hline 71 & .337 & 1.000 & 1.000 \\
\hline 74 & .337 & 1.000 & 1.000 \\
\hline 75 & .337 & 1.000 & 1.000 \\
\hline 76 & .337 & 1.000 & 1.000 \\
\hline
\end{tabular}

Sumber: Data yang Diolah (2017)

Dikatakan tidak terjadi outlier jika p1 p2 > 0.00 (Ghozali, 2014: 85). Berdasarkan hal tersebut, dalam penelitian ini masih terjadi outlier, karena p1 atau p2 responden nomor 7, 20, dan 108 memiliki nilai 0,00. Dikarenakan jika responden nomor 7, 20, dan 
108 dihapus, maka data menjadi tidak normal, maka data tersebut dipertahankan, mengingat jumlah sampel yang terbilang minim.

\section{d. Multikolinieritas dan Singularitas}

Multikolinieritas dan singularitas dideteksi dari determinan matriks covarians yang jika nilainya sangat kecil, aplikasi akan memunculkan tanda peringatan (warning) (Ferdinand, 2014: 63). Dikatakan tidak terkena multikolinearitas dan singularitas jika eigenvalues determinant of sample covariance matrix jauh diatas nol (Ferdinand, 2014:120). Maka disimpulkan bahwa tidak terkena multikolinearitas dan singularitas, sebagaimana dapat dilihat pada tabel 4.5. berikut::

Tabel. 8

Multikolinearitas dan Singularitas

Sample Covariances (Group number 1)

\begin{tabular}{llllllllll}
\hline & KK5 & KK4 & KK3 & KK1 & STK1 & STK2 & STK3 & EKI5 & EKI2 \\
\hline KK5 & .253 & & & & & & & & \\
\hline KK4 & .085 & .221 & & & & & & & \\
\hline KK3 & .067 & .054 & .181 & & & & & & \\
\hline KK1 & .103 & .039 & .062 & .174 & & & & & \\
\hline STK1 & .025 & .053 & .048 & .014 & .161 & & & & \\
\hline STK2 & .081 & .052 & .043 & .035 & .055 & .195 & & & \\
\hline STK3 & .044 & .029 & .040 & .006 & .075 & .099 & .238 & & \\
\hline EKI5 & .037 & .038 & .044 & .028 & .052 & .041 & .045 & .238 & \\
\hline EKI2 & .071 & .057 & .063 & .055 & .048 & .061 & .040 & .073 & .235 \\
\hline & KK5 & KK4 & KK3 & KK1 & STK1 & STK2 & STK3 & EKI5 & EKI2 \\
\hline KK5 & .253 & & & & & & & & \\
\hline KK4 & .085 & .221 & & & & & & & \\
\hline KK3 & .067 & .054 & .181 & & & & & & \\
\hline KK1 & .103 & .039 & .062 & .174 & & & & & \\
\hline STK1 & .025 & .053 & .048 & .014 & .161 & & & & \\
\hline STK2 & .081 & .052 & .043 & .035 & .055 & .195 & & & \\
\hline STK3 & .044 & .029 & .040 & .006 & .075 & .099 & .238 & & \\
\hline EK15 & .037 & .038 & .044 & .028 & .052 & .041 & .045 & .238 & \\
\hline EKI2 & .071 & .057 & .063 & .055 & .048 & .061 & .040 & .073 & .235 \\
\hline Condition & & & & & & &
\end{tabular}

Condition number $=7.176$

Eigenvalues

635.274.223.176.156.144. 102. 098 .089

Determinant of sample covariance matrix $=.000$

Sumber: Data yang Diolah (2017) 
1) Uji Hipotesis (Analisis Kausalitas)

Analisis kausalitas dilakukan untuk mengetahui hubungan antar variabel. Pada penelitian ini dilakukan pengujian kausalitas untuk dapat mengetahui hubungan yang terjadi antara workplace spirituality (spiritualitas di tempat kerja), etika kerja Islam, dan kinerja karyawan. Pada kerangka pemikiran diketahui bahwa $\mathrm{H}_{1}, \mathrm{H}_{2}$, dan $\mathrm{H}_{3}$ menduga terdapat pengaruh signifikan pada hubungan antar konstruk yang menjadi hipotesis.

Berikut ini adalah tabel hasil analisis data yang menunjukkan hubungan antar variabel:

Tabel. 9

\section{Hubungan Antar Variabel}

Regression Weights: (Group number 1 - Default model)

\begin{tabular}{cccccccc}
\hline & & & Estimate & S.E. & C.R. & P & Label \\
\hline EKI & $<---$ & STK & .632 & .197 & 3.216 & .001 & par_1 \\
\hline KK & $<---$ & EKI & .416 & .235 & 1.771 & .077 & par_2 \\
\hline KK & $<---$ & STK & .166 & .190 & .871 & .384 & par_3 \\
\hline
\end{tabular}

Sumber: Data yang Diolah (2017)

Tabel. 10

Standardized Regression Weights: (Group number 1 Default model)

\begin{tabular}{cccc}
\hline & & & Estimate \\
\hline EKI & $<---$ & STK & .595 \\
\hline KK & $<---$ & EKI & .540 \\
\hline KK & $<---$ & STK & .203 \\
\hline
\end{tabular}

Sumber: Data yang Diolah (2017)

Dari tabel. 9 dan 10, dapat dilihat bahwa variabel yang mengalami hubungan kausalitas hanya pada satu hubungan, yakni antara workplace spirituality dan etika kerja Islam. Sedangkan etika kerja Islam terhadap kinerja karyawan, serta workplace spirituality terhadap kinerja karyawan, pada keduanya tidak mengalami hubungan kausalitas. Secara 
lengkap, hal tersebut dapat dilihat pada beberapa poin penjelasan mengenai hipotesis berikut ini:

$\mathrm{H}_{1}$ : Ada pengaruh signifikan antara workplace spirituality terhadap etika kerja Islam. Dari tabel 4.6. diketahui bahwa hubungan antara workplace spirituality terhadap etika kerja Islam memiliki p-value < 0,05 sebesar 0,001, dimana artinya workplace spirituality berpengaruh signifikan terhadap etika kerja Islam, maka $\mathrm{H}_{1}$ diterima. Sedangkan besarnya pengaruh langsung antara workplace spirituality terhadap etika kerja Islam dapat dilihat pada table. 10 yakni sebesar 0,595.

$\mathrm{H}_{2}$ : Tidak ada pengaruh signifikan antara etika kerja Islam terhadap kinerja karyawan. Dari table. 9 diketahui bahwa hubungan antara etika kerja Islam terhadap kinerja karyawan memiliki $p$-value $>0,05$, yaitu sebesar 0,077, dimana artinya etika kerja Islam tidak berpengaruh signifikan terhadap kinerja karyawan, maka $\mathrm{H}_{2}$ ditolak.

$\mathrm{H}_{3}$ : Tidak ada pengaruh signifikan antara workplace spirituality terhadap kinerja karyawan. Dari table. 9 diketahui bahwa hubungan antara workplace spirituality terhadap kinerja karyawan memiliki $p$-value $>0,05$, yaitu sebesar 0,384, dimana artinya workplace spirituality tidak berpengaruh signifikan terhadap kinerja karyawan, maka $\mathrm{H}_{3}$ ditolak.

2) Peranan Etika Kerja Islam sebagai Variabel Perantara

Dalam analisis data, juga diperoleh hasil mengenai ada tidaknya pengaruh etika kerja Islam dalam menjalankan peran mediasi pada hubungan antara workplace spirituality dan kinerja karyawan. Ferdinand (2014: 305) menyatakan bahwa salah satu cara dalam menguji hipotesis perantara yang dikembangkan adalah dengan Sobel Test dengan menggunakan rumus berikut:

$$
z=\frac{\mathrm{ab}}{\sqrt{b^{2} \mathrm{SE}^{2}{ }_{a}+a^{2} \mathrm{SE}_{b}^{2}}}
$$


Seperti halnya hipotesis lainnya, hipotesis ini diterima bila menghasilkan nilai $z \geq 1.98$. Berikut penghitungannya:

$$
\begin{aligned}
z & =\frac{(0,595)(0,540)}{\sqrt{(0,540)^{2}(0,197)^{2}+(0,595)^{2}(0,235)^{2}}} \\
& =1,85
\end{aligned}
$$

Karena $\mathrm{CR}<1,98$, maka dapat disimpulkan bahwa etika kerja Islam sebagai variabel mediasi tidak memiliki pengaruh signifikan.

Selain dengan menggunakan rumus Sobel Test, peran variabel perantara juga dapat dilihat dari tabel berikut:

Tabel. 11

Hubungan Antar Variabel

\begin{tabular}{llll}
\hline & STK & EKI & KK \\
\hline EKI & .000 & .000 & .000 \\
\hline KK & .263 & .000 & .000 \\
\hline
\end{tabular}

Sumber: Data yang Diolah (2017)

Mediasi etika kerja Islam ditunjukkan dari p-value $>0.05$. Maka disimpulkan bahwa variabel etika kerja Islam tidak memiliki pengaruh mediasi.

\section{E. Pembahasan}

\section{Pengaruh Workplace Spirituality terhadap Etika Kerja Islam}

Hasil pengujian kausalitas menunjukkan bahwa workplace spirituality berpengaruh signifikan terhadap etika kerja Islam. Hal ini sesuai dengan penelitian sebelumnya yang dilakukan oleh Giacalone dan Jurkiewicz (2003) yang menyatakan bahwa spiritualitas akan berkorelasi dengan persepsi pelanggaran etika yang lebih tinggi dalam kasus ketika legalitas suatu isu yang diberikan tidak jelas.

Hal ini menunjukkan bahwa workplace spirituality masih menjadi faktor penentu dalam memunculkan etika kerja Islam yang dimiliki oleh karyawan. Artinya, jika workplace spirituality tinggi, maka akan menyebabkan tingginya pula etika kerja Islam karyawan. Dalam hal ini, manajemen SDM pada Rumah Sakit perlu 
meningkatkan orientasi workplace spirituality pada karyawannya, dalam rangka meningkatkan etika kerja Islam karyawan.

\section{Pengaruh Etika Kerja Islam terhadap Kinerja Karyawan}

Hasil pengujian kausalitas menunjukkan bahwa etika kerja Islam tidak berpengaruh signifikan terhadap kinerja karyawan. Hal ini sebagaimana temuan Budiman (2009) yang menyebutkan bahwa etika kerja Islam tidak mempunyai pengaruh yang signifikan terhadap kinerja karyawan KJKS BMT di Kecamatan Rembang. Ketiadaan hubungan kausalitas antara etika kerja Islam dengan kinerja karyawan ini berbeda dengan beberapa hasil penelitian yang menunjukkan adanya hubungan pada keduanya sebagaimana temuan Chanzanagh dan Akbarnejad (2011); A.J. Ali dan Owaihan (2008); Nizam et al. (2016); Nurmatias (2015); Aji (2010); dan Yousef (2008). Hal ini mungkin dilatarbelakangi perbedaan kondisi objek penelitian antara dalam negeri dengan di luar negeri, mengingat indikator etika kerja Islam yang digunakan masih mengadopsi dari hasil penelitian yang dilakukan di luar negeri. Dengan demikian, gap penelitian pada hubungan antara etika kerja Islam dengan kinerja karyawan masih sangat terbuka untuk menjadi latarbelakang pada penelitian-penelitian berikutnya.

\section{Pengaruh Workplace Spirituality terhadap Kinerja Karyawan}

Hasil pengujian kausalitas menunjukkan bahwa workplace spirituality juga tidak berpengaruh signifikan terhadap kinerja karyawan. Hal ini sebagaimana temuan Pratama (2014) dimana spiritualitas secara parsial tidak berpengaruh terhadap kinerja. Sebagaimana pada hubungan antara etika kerja Islam dengan kinerja karyawan, pada hubungan antara workplace spirituality dengan kinerja karyawan juga masih menyisakan gap penelitian yang masih dapat dikembangkan menjadi masalah penelitian pada penelitia-penelitian berikutnya.

\section{F. Simpulan}

Kesimpulan penelitian ini dimaksudkan untuk mempermudah dalam pemahaman mengenai hasil penelitian. 
Berikut dipaparkan secara singkat mengenai hasil dari penelitian ini:

1. Workplace spirituality berpengaruh signifikan terhadap etika kerja Islam sebesar 0,595, dengan signifikansi sebesar 0,001.

2. Etika kerja Islam tidak berpengaruh signifikan terhadap kinerja karyawan, karena memiliki p-value > 0,05, yaitu sebesar 0,077.

3. Workplace spirituality tidak berpengaruh signifikan terhadap kinerja karyawan, karena memiliki p-value > 0,05, yaitu sebesar 0,384.

4. Etika kerja Islam sebagai variabel mediasi pada hubungan kausalitas antara workplace spirituality dan kinerja karyawan tidak memiliki pengaruh signifikan, karena $C R<1,98$, dan p-value $>0.05$.

\section{G.Saran}

Studi ini diharapkan mampu memberikan implikasi secara metodologis maupun praktis. Berikut adalah penjelasannya:

\section{Implikasi Metodologis}

Hasil penelitian ini diharapkan mampu memberikan pemahaman kepada kalangan akademis dalam memahami pola hubungan workplace spirituality, etika kerja Islam, dan kinerja karyawan, yang diharapkan dapat menjadi bahan diskusi atau referensi untuk mengungkap persepsi terhadap fenomena dalam konteks yang berbeda. Ruang lingkup studi ini juga hanya difokuskan pada karyawan dari Rumah Sakit PKU Muhammadiyah Surakarta dan Rumah Sakit IPHI Pedan, Klaten, sehingga berdampak pada keterbatasan generalisasi studi. Hal tersebut mengisyaratkan perlunya studi lanjutan untuk menggeneralisasikan studi pada konteks yang lebih luas.

\section{Implikasi Praktis}

Studi ini diharapkan dapat memberikan pemahaman pada praktisi terhadap upaya-upaya dalam meningkatkan etika kerja Islam melalui workplace spirituality. Hal ini memiliki implikasi bagi perusahaan untuk memperkuat stimulus yang dapat meningkatkan etika kerja Islam. Stimulus yang diberikan dapat berupa peningkatan kualitas orientasi workplace spirituality dalam bekerja. 


\section{DAFTAR PUSTAKA}

Aji, G. 2010. “Analisis Pengaruh Etika Kerja Islam Terhadap Komitmen Organisasi dengan Komitmen Profesi Sebagai Variabel Intervening (Studi Empiris Terhadap Internal Auditor Bank di Jawa Tengah)", (November), 93-108.

Albuquerque, Isabel Faro, Rita Campos Cunha, Luis Dias Martins, and Armando Britosa. 2014

. Journal of Organizational Change Management, Vol.27 (1);pp.5982.

Ashmos, D., \& Duchon, D. 2000. "Spirituality at work". Journal of Management Inquiry, Vol. 9, pp. 134-145.

Ali, A. J., \& Owaihan, A. 2008. Islamic work ethic : a critical review, 15(1), 5-19. https://doi.org/10.1108/13527600810848791.

Budiman, F. A. 2009. “Pengaruh Kepemimpinan dan Etos Kerja Islami Terhadap Kinerja Karyawan di Koperasi Jasa Keuangan Syari'ah Baitul Maal Wat Tamwil di Kecematan Rembang". Analisis Manajemen, 4(1), 11-28.

Cavanagh, G. F. \& Banduch, M. R. 2002. “Virtue as a Benchmark for Spirituality in Business. Journal of Business Ethics", Vol. 38, pp. 109-177.

Chanzanagh, E. H., \& Akbarnejad, M. 2011. “Social and The meaning and dimensions of Islamic work ethic: initial validation of a multidimensional IWE in Iranian society". Procedia Social and Behavioral Sciences, 30, 916-924. https://doi. org/10.1016/j.sbspro.2011.10.178.

Ferdinand, Augusty. 2002. Structural Equation Modelling dalam Penelitian Manajemen: Edisi Kedua. Semarang: Badan Penerbit Universitas Diponegoro.

Ferdinand, Augusty. 2014. Metode Penelitian Manajemen (Pedoman Penelitian untuk Penelitian Skripsi, Tesis, dan Disertasi Ilmu Manajemen: Edisi Kelima. Diponegoro: Badan Penerbit Universitas Diponegoro. 
Fry, L. W. 2003. Toward a Theory of Spiritual Leadership. The Leadership Quarterly, Vol. 14, pp. 693-727.

Fry, L.W. 2005. Toward a Theory of Ethical and Spiritual Well-being, and Corporate Social Responsibility through Spiritual Leadership. In: C. Dunne, R.A.

Gani, Aahad M. Osman, Junaidah Hasyim, and Yusuf Ismail. 2013. "Establishing Linkages Between Religiosity and Spirituality on Employee Relations. Emerald Group Publishing", Vol.35 (4), pp. 360-376.

Ghozali, I. 2014. Model Persamaan Struktural: Konsep dan Aplikasi dengan Program AMOS 22.0 Update Bayesian SEM (Ed. ke-6). Semarang: UNDIP Press.

Ghozali, I., \& Latan, H. 2015. Partial Least Squares Konsep, Teknik dan Aplikasi menggunakan Program SmartPLS 3.0 untuk Penelitian Empiris. Semarang: UNDIP Press.

Giacalone, R. A., \& Jurkiewicz, C. L. 2003. Handbook of workplace spirituality and organizational performance (Me Sharpe).

Giacalone, R.A. and Jurkiewicz, C.L. 2003. "Right from Wrong: the Influence of Spirituality on Perceptions of Unethical Business Activities". Journal of Business Ethics, Vol. 46 (1), pp. 85-97.

Giacolone and C.L. Jurkiewicz, Editors, Positive psychology and corporate responsibility, Information Age Publishing, Greenwich, CT.

Hair J.F. et.al. 1995. Multivariate Data Analysis With Reading, Fourth Edition, Prentice Hall. New Jersey.

Harrington, W; Preziosi, R; and Gooden, D. 2001. "Perceptions of Workplace Spirituality among Professionals and Executives". Employee Responsibilities and Rights Journal, Vol. 13 (3), pp.155-163.

Hasibuan, 2011. Manajemen Sumber Daya Manusia: Edisi Revisi. Jakarta: Bumi Aksara.

Hayati, K., \& Caniago, I. 2012. "Islamic Work Ethic: The Role of Intrinsic Motivation, Job Satisfaction , Organizational Commitment and Job Performance", 65(ICIBSoS), 272-277. https://doi.org/10.1016/j.sbspro.2012.11.122. 
Kolodinsky, R. W., Giacalone, R. A. \& Jurkiewicz, C. L. 2008. "Workplace values and outcomes: Exploring personal, organizational, and interactive workplace spirituality". Journal of Business Ethics, 81, 465-480.

Kumpikaite, V. 2009. Attitudes of spirituality: Pilot study from Lithuania. The Business Review, Cambridge, 13, 271-278.

Kuncoro, Mudrajad. 2009. Metode Riset untuk Bisnis dan Ekonomi: Edisi 3. Jakarta: Penerbit Erlangga.

Mangkunegara, A. A., Anwar, Prabu. 2001. Manajemen Sumber Daya Perusahaan. Cetakan ketiga. Bandung: PT. Remaja Rosdakarya.

Mathis, Robert L., dan John, H. Jackson. 2002. Manajemen Sumber Daya Manusia. Jakarta: Salemba Empat.

Milliman, J., Ferguson, J. J., Trickett, D. and Condemi, B. 1999. “Spirit and community at Southwest Airlines: An investigation of a spiritual value s-based model". Journal of Organizational Change Management, Vol. 12 (3); pp. 221-233.

Nizam, S., Sarah, S., Abdullah, M. S., \& Osman, A. 2016. “The Effect of Islamic Work Ethics on Organizational Commitment". Procedia Economics and Finance, 35(October 2015), 582-590. https://doi.org/10.1016/S2212-5671(16)00071-X.

Nurmatias, F. 2015. "Pengaruh Etika Kerja Islam, Komitmen Organisasi Terhadap Kinerja Karyawan di Institut Agama Islam Tafaqquh Fiddin Dumai". Jurnal Tamaddun Ummah, 1(1), 1-14.

Pratama, Abdul Aziz Nugraha. 2014. "Pengaruh Spiritualitas, Intelektualitas, dan Profesionalisme terhadap Kinerja Dosen STAIN Salatiga". Vol. 8 (2), pp. 415-436.

Rais, R., Adolfina, \& Dotulong, L. 2016. "Komitmen Organisasi, Kepuasan Kerja dan Lingkungan Kerja terhadap Kinerja Karyawan di PT. PLN (PERSERO) Wilayah Suluttenggo". Jurnal Berkala Ilmiah Efisiensi, 16(1), 185-197.

Rosita, T., \& Yuniati, T. 2016. “Pengaruh Kepuasan Kerja Terhadap Kinerja Karyawan dengan Komitmen Organisasional Sebagai 
Moh Rifqi Khairul Umam \& Zakky Fahma Auliya

Variabel Intervening". Jurnal Ilmu Dan Riset Manajemen, 5(1), 1-20.

Soha, Hazalina Mat, Abdullah Osman, Sharul Nizam Salahuddin, Safizal Abdullah, and Nor Faizzah Ramlee. 2016. "The Relationship of Work Influence, Sense of Community, and Individual Spirituality towards Organizational Performance". Procedia Economics and Finance, Vol.35; 591596.

Yousef, D. A. 2008. Human Relations, 53(11750), 513-537. 